\title{
ORIGINAL
}

ARTICLES

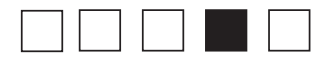

\section{Satisfaction, Motivation, and Retention in Academic Faculty Incentive Compensation Systems: A CERA Survey}

Deanna R. Willis, MD, MBA; Jane Williams, PhD, MS; Kevin Gebke, MD; George Bergus, MD, MA-Ed

\begin{abstract}
BACKGROUND AND OBJECTIVES: The use of incentive compensation in academic family medicine has been a topic of interest for many years, yet little is known about the impact of these systems on individual faculty members. Better understanding is needed about the relationship of incentive compensation systems (ICSs) to ICS satisfaction, motivation, and retention among academic family medicine faculty.
\end{abstract}

METHODS: The Council of Academic Family Medicine (CAFM) Educational Research Alliance (CERA) conducted a nationwide survey of its members in 2013. This study reports the results of the incentive compensation question subset of the larger omnibus survey.

RESULTS: The overall response rate was 53\%. The majority (70\% [360/511]) of academic faculty reported that they are eligible for some type of incentive compensation. The faculty reported moderate satisfaction, with only $38 \%$ being satisfied or highly satisfied with their ICS. Overall mean motivation and intent to remain in their current position were similar. The percentage of total income available as an incentive explained less than $10 \%$ of the variance of those outcomes. Faculty perceptions of appropriateness of the measures, understanding of the measurement and reward systems, and perception of due process are all related to satisfaction with the ICS, motivation, and retention.

CONCLUSIONS: ICSs are common in academic family medicine, yet most faculty do not find them to motivate their choice of activities or promote staying in their current position. Design and implementation are both important in promoting faculty satisfaction with the ICS, motivation, and retention.

(Fam Med. 2018;50(2):113-22.)

doi: 10.22454/FamMed.2018.752167

$\mathbf{T}$ he use of incentive compensation in academic medicine has been a topic of interest for many years..$^{1-8} \mathrm{~A} 2006$ systematic review of implemented incentive compensation system (ICS) programs in academic units concluded that incentive compensation was associated with positive financial impact and increased professional productivity in clinical and scholarly activity. ${ }^{9}$

Despite the intuitive benefit of rewarding performance with incentive pay, the application of self-determination theory to compensation systems suggests that the autonomous motivation of an individual can be harmed by an ICS. ${ }^{8,10}$ Compensation has been demonstrated as a significant predictor of overall job satisfaction for clinical track physicians. ${ }^{11}$ Recent work showed most physicians expressed a negative view of an ICS in an academic health center, with the lowest-scoring related to plan complexity and choice of metrics. ${ }^{12}$ Yet, little remains known about the penetration of academic incentive compensation plans in family medicine, the psychological reactions toward those systems, and the impact of those reactions on faculty physician satisfaction, motivation, and retention.

By using incentive payments to link the physician's actions to the larger organizational goal, the organization hopes that the physician will be more likely to perform certain behaviors. Yet, physicians may not be motivated to act in the interest of the larger organization if there is a conflict between the goal of the individual physician and the goal of the organization..$^{13}$ Research on clinical incentives has shown that incentivizing performance improvement in one area can result in improvement in that measure, but may also be associated with decreasing performance in other nonincentivized areas, ${ }^{14-17}$

From the Indiana University School of Medicine, Department of Family Medicine (Drs Willis and Gebke); Indiana University Purdue University at Indianapolis, School of Science, Department of Psychology (Dr Williams); and University of Iowa Carver College of Medicine, Department of Family Medicine (Dr Bergus). 
suggesting that incentives cause individuals to make trade-offs when choosing activities to focus on. Incentive formulas that are too simple lead to lack of attention to key strategic areas, while incentive formulas that are too complex lead to lack of understanding and lack of motivation for the physician. ${ }^{12,18,19}$ While design and implementation of ICS impact whether or not those tradeoffs exist for academic physicians, and impact satisfaction, motivation, and retention, better understanding is needed of the relationship of satisfaction, motivation, and retention with the categories of incentives offered. ${ }^{12,20}$

Organizational psychology and business management principles indicate that an individual's knowledge of his or her respective compensation system, ${ }^{19}$ positive perceptions of due process related to the design and implementation of the compensation system (eg, adequate notice, judgment based on evidence and fair hearing), ${ }^{21}$ perceived validity, ${ }^{12,22}$ procedural justice, ${ }^{23}$ distributive justice, and alignment with strategic objectives, ${ }^{24}$ are all important predictors of both a successful ICS, and participant satisfaction with an ICS. ${ }^{13,25}$

Most outcome reports of academic ICSs have focused on the financial impact to an academic department or unit, ${ }^{26}$ changes in clinical and academic productivity, ${ }^{27,28}$ and retention rates for the entire unit, ${ }^{28}$ rather than the impact of the ICS on the satisfaction, motivation, and retention of individual faculty. Without knowledge of the impact of such systems on individual faculty members' perceptions, there is a risk that these systems, which are intended to reward productive faculty members, may actually lead to harm, ${ }^{29}$ including increased rates of faculty turnover, ${ }^{30,31}$ and subsequent exacerbation of the shortage of qualified academic family medicine educators and researchers.

This study attempts to fill that gap by providing further empirical evidence about the impact of diverse ICS programs on faculty satisfaction, motivation, and retention by exploring the relationships between the categories of incentives offered, the ICS design, and implementation of the ICS, with ICS satisfaction, motivation, and retention.

\section{Methods}

To better understand the satisfaction, motivation, and retention of academic faculty, we developed a set of 35 survey questions to explore aspects of ICS design and implementation and individual faculty outcomes based on organizational psychology and business management principles of incentive compensation systems. ${ }^{12,13,19,21-25}$ The incentive compensation subset of questions is shown in Table 1. Two physician faculty members who were not involved in survey design were asked to complete the question subset prior to distribution of the CERA survey to establish face validity. We specifically asked faculty to report how their ICS impacted their motivation to devote time and energy to specific activities within the scope of academic medicine, their intentions to remain with the organization, and their overall satisfaction with the ICS.

\section{Setting}

This project is part of the larger Council of Academic Family Medicine (CAFM) Educational Research Alliance (CERA) omnibus survey. The study was approved by the American Academy of Family Physicians Institutional Review Board and was reviewed and considered exempt by the Institutional Review Board of Indiana University School of Medicine. The survey methods we used are similar to the previously described CERA 2011 Residency Director Survey. ${ }^{32}$

The survey was designed as an omnibus survey incorporating questions from several distinct investigator-initiated subprojects all related to academic medicine faculty, in addition to a set of demographic questions common to all subprojects. ${ }^{33}$ US-based physician active members of the CAFM organizations (Society of Teachers of Family Medicine, Association of Departments of Family Medicine, Association of Family Medicine Residency Directors, and the North American Primary Care Research Group) were solicited for participation in the study in early 2013. Active members were defined as those who have attended a CAFM organization meeting since January 1,2010 , or were listed as a member of a committee or group within these organizations.

\section{Data Collection}

Survey support staff of STFM surveyed potential respondents electronically with an initial email invitation for participation. The survey included a personalized greeting, a letter signed by the presidents of each of the four participating organizations urging participation, and a link to the survey. STFM staff sent nonresponders two follow-up emails encouraging participation.

\section{Data Analysis}

We used IBM SPSS Statistics Version 20 to perform the data analysis for this study. We completed descriptive statistics for the responses to questions from the common demographic question set and the ICSspecific question set. We captured all responses to questions assessing faculty perceptions and reactions on a 5-point Likert scale. By using twotailed $t$-tests assuming equal variance we evaluated differences in satisfaction, motivation, and retention between groups of responses for demographic subsets including incentive amounts, types of incentives, and elements of the ICSs. Lastly, we used correlation, linear regression and multivariate analysis of variance (MANOVA) to examine the research questions of interest.

To better understand variability in satisfaction, motivation, and retention, we first examined various structural domain aspects of the ICSs, and then examined faculty perceptions of the implementation as predictors of the outcomes of interest. In 
particular, we asked faculty whether the behaviors being targeted by the ICS were appropriate (two items: perceptions of appropriateness and perceptions of validity and credibility), whether they understood the ICS (two items: understanding how their ICS measures them and rewards them), and whether they thought the system was implemented with due process (10 items: adequate notice, fair distribution, clear appeal mechanisms, timely and frequent reporting, meaningful input into design, applied consistently, aligned with strategic objectives, information used is credible and valid).

\section{Results}

The all-member CERA survey was completed by 581 individuals out of 1,099 potential respondents for a response rate of $52.9 \%$. The incentive compensation system set of questions was completed by 511 individuals for a response rate of $46.5 \%$. The majority of respondents were non-Hispanic white physicians of assistant or associate professor rank (Table 2). Almost three-fourths (70\%,
360/511) of academic faculty reported that they were eligible for some type of incentive compensation. Of those reporting that they were eligible for an incentive, $68 \%$ reported that $1 \%$ to $10 \%$ of their total income could come from incentives, $26 \%$ reported $11 \%$ to $25 \%$, and the final $6 \%$ indicated the percentage was greater than $25 \%$.

Overall, as assessed on a 5-point scale with 1 being strongly dissatisfied and 5 being strongly satisfied, the faculty reported moderate levels of satisfaction $(\mathrm{m}=3.09, \mathrm{SD}=1.08)$,

Table 1: Incentive Compensation Question Subset

\begin{tabular}{|c|c|c|}
\hline Domain & Question & Response Choices \\
\hline Structural & $\begin{array}{l}\text { Please indicate which types of incentive } \\
\text { compensation that you are eligible for. } \\
\text { Mark all that apply. }\end{array}$ & $\begin{array}{l}\text { - Clinical productivity } \\
\text { - Clinical quality } \\
\text { - Teaching productivity } \\
\text { - Teaching quality } \\
\text { - Research or scholarly productivity }\end{array}$ \\
\hline Structural & $\begin{array}{l}\text { What is the approximate total amount } \\
\text { of incentive compensation available } \\
\text { to you on an annual basis in terms of } \\
\text { percent of your total income: }\end{array}$ & $\begin{array}{ll}\cdot & 0 \% \\
- & 1-10 \% \\
- & 11-25 \% \\
- & 26-50 \% \\
- & \text { Greater than } 50 \% \\
\end{array}$ \\
\hline Structural & $\begin{array}{l}\text { Which of the following characteristics } \\
\text { are present in your ICS? (mark all that } \\
\text { apply) }\end{array}$ & $\begin{array}{l}\text { - } \\
\text { - } \text { Automated tracking (reports generated without } \\
\text { your input) } \\
\text { - Manual tracking (reports generated by you and } \\
\text { submitted) } \\
\text { - Team based or group based incentives } \\
\text { - Criteria that eliminate eligibility from ICS if not } \\
\text { met } \\
\text { - Citizenship or other qualitative component of } \\
\text { cooperation }\end{array}$ \\
\hline Satisfaction & $\begin{array}{l}\text { Please rate your overall satisfaction } \\
\text { with your ICS. }\end{array}$ & $\begin{array}{l}\text { 1. Strongly dissatisfied } \\
\text { 2. Somewhat dissatisfied } \\
\text { 3. Neither dissatisfied nor satisfied } \\
\text { 4. Somewhat satisfied } \\
\text { 5. Strongly satisfied }\end{array}$ \\
\hline & $\begin{array}{l}\text { Please rate your level of agreement } \\
\text { with the following statements: }\end{array}$ & \\
\hline Understanding & $\begin{array}{l}\text { I understand our ICS and how I am } \\
\text { measured. }\end{array}$ & \multirow{4}{*}{$\begin{array}{l}\text { 1. Strongly disagree } \\
\text { 2. Disagree } \\
\text { 3. Neutral } \\
\text { 4. Agree } \\
\text { 5. Strongly agree }\end{array}$} \\
\hline Understanding & $\begin{array}{l}\text { I understand how I am rewarded in our } \\
\text { ICS. }\end{array}$ & \\
\hline Due process & $\begin{array}{l}\text { Our ICS incentivizes activities which } \\
\text { are highly aligned with strategic } \\
\text { objectives of our bigger system. }\end{array}$ & \\
\hline Due process & $\begin{array}{l}\text { I was given adequate notice of how the } \\
\text { ICS worked, including how it would be } \\
\text { measured, before it went into effect. }\end{array}$ & \\
\hline
\end{tabular}


Table 1, continued

\begin{tabular}{|c|c|c|}
\hline Domain & Question & Response Choices \\
\hline Appropriateness & $\begin{array}{l}\text { The activities measured by the ICS are } \\
\text { appropriate for the incentive system. }\end{array}$ & \multirow{12}{*}{$\begin{array}{l}\text { 1. Strongly disagree } \\
\text { 2. Disagree } \\
\text { 3. Neutral } \\
\text { 4. Agree } \\
\text { 5. Strongly agree }\end{array}$} \\
\hline Due process & $\begin{array}{l}\text { Our ICS distributes incentive dollars } \\
\text { fairly. }\end{array}$ & \\
\hline Due process & $\begin{array}{l}\text { Clear appeal mechanisms exist for } \\
\text { me to question or refute an ICS } \\
\text { measurement or payment. }\end{array}$ & \\
\hline Due process & $\begin{array}{l}\text { I receive ICS reports that are timely } \\
\text { and frequent enough for me to take } \\
\text { action to impact my ICS payment. }\end{array}$ & \\
\hline Due process & $\begin{array}{l}\text { Our ICS system measures activities } \\
\text { which are important to academic family } \\
\text { medicine. }\end{array}$ & \\
\hline Due process & $\begin{array}{l}\text { Our ICS system rewards activities } \\
\text { which are important to academic family } \\
\text { medicine. }\end{array}$ & \\
\hline Due process & $\begin{array}{l}\text { I had input into how our ICS is } \\
\text { structured. }\end{array}$ & \\
\hline Due process & $\begin{array}{l}\text { The standards in the ICS systems are } \\
\text { applied consistently across faculty/ } \\
\text { physicians. }\end{array}$ & \\
\hline Appropriateness & $\begin{array}{l}\text { The information used to assess my } \\
\text { performance in the ICS system is valid } \\
\text { and credible. }\end{array}$ & \\
\hline Teamwork & $\begin{array}{l}\text { Our ICS system has increased the } \\
\text { amount of teamwork within our unit. }\end{array}$ & \\
\hline Motivation & $\begin{array}{l}\text { Our ICS system motivates me to } \\
\text { give more time or energy to certain } \\
\text { activities. }\end{array}$ & \\
\hline Motivation & $\begin{array}{l}\text { Our ICS system motivates me to } \\
\text { give more time or energy to clinical } \\
\text { activities. }\end{array}$ & \\
\hline Domain & Question & Response Choices \\
\hline Motivation & $\begin{array}{l}\text { Our ICS system motivates me to give } \\
\text { more time or energy to scholarship } \\
\text { activities. }\end{array}$ & \multirow{6}{*}{$\begin{array}{l}\text { 1. Strongly disagree } \\
\text { 2. Disagree } \\
\text { 3. Neutral } \\
\text { 4. Agree } \\
\text { 5. Strongly agree }\end{array}$} \\
\hline Motivation & $\begin{array}{l}\text { Our ICS system motivates me to } \\
\text { give more time or energy to teaching } \\
\text { activities. }\end{array}$ & \\
\hline Motivation & $\begin{array}{l}\text { Our ICS system motivates me to give } \\
\text { more time or energy to leadership } \\
\text { activities. }\end{array}$ & \\
\hline Retention & $\begin{array}{l}\text { Our ICS system increases the likelihood } \\
\text { that I will remain with my current } \\
\text { employer. }\end{array}$ & \\
\hline Due process & $\begin{array}{l}\text { Our ICS system will help me get } \\
\text { promoted. }\end{array}$ & \\
\hline Structural & $\begin{array}{l}\text { The pay I receive through our } \\
\text { ICS system is necessary for my } \\
\text { compensation to be equivalent to what } \\
\text { I would receive in another employment } \\
\text { situation. }\end{array}$ & \\
\hline
\end{tabular}


Table 2: Descriptive Statistics of Survey Respondents

\begin{tabular}{|l|c|c|}
\hline \multicolumn{1}{|c|}{ Item } & $\begin{array}{c}\% \text { Yes (Number } \\
\text { of Respondents) }\end{array}$ & $\begin{array}{c}\text { \% No (Number of } \\
\text { Respondents) }\end{array}$ \\
\hline Male & $58.0 \%(334)$ & $42.0 \%(242)$ \\
\hline Less than 50 years old & $45.7 \%(264)$ & $54.3 \%(314)$ \\
\hline Non-Hispanic white ethnicity & $84.7 \%(483)$ & $15.3 \%(97)$ \\
\hline Assistant or associate rank & $63.4 \%(364)$ & $36.9 \%(187)$ \\
\hline MD or DO degree & $94.1 \%(543)$ & $5.9 \%(34)$ \\
\hline Primary role of teaching or research & $48.0 \%(276)$ & $52.0 \%(302)$ \\
\hline Less than 3 half days clinical time & $52.2 \%(301)$ & $47.9 \%(276)$ \\
\hline Eligible for clinical productive incentive & $83.3 \%(300)$ & $16.7 \%(60)$ \\
\hline Eligible for clinical quality incentive & $46.9 \%(169)$ & $53.1 \%(191)$ \\
\hline Eligible for clinical productivity and clinical quality incentive & $43.9 \%(155)$ & $56.1 \%(198)$ \\
\hline Eligible for teaching productivity incentive & $32.8 \%(118)$ & $67.2 \%(242)$ \\
\hline Eligible to teaching quality incentive & $23.6 \%(85)$ & $76.4 \%(275)$ \\
\hline Eligible for teaching productivity and teaching quality incentive & $13.1 \%(45)$ & $86.9 \%(298)$ \\
\hline Eligible for research productivity incentive & $40.8 \%(147)$ & $59.2 \%(213)$ \\
\hline $\begin{array}{l}\text { Eligible for clinical productivity, teaching productivity, and research productivity } \\
\text { incentive }\end{array}$ & $20.1 \%(69)$ & $79.9 \%(274)$ \\
\hline Eligible for clinical quality and teaching quality incentive & $16.0 \%(55)$ & $84.0 \%(288)$ \\
\hline
\end{tabular}

motivation ( 1 being strongly disagree and 5 being strongly agree; $\mathrm{m}=2.61$, $\mathrm{SD}=.86)$, or anticipated retention (1 being strongly disagree and 5 being strongly agree; $\mathrm{m}=2.67, \mathrm{SD}=1.01, \mathrm{Ta}-$ ble 3 ), with only $38 \%$ of faculty reported as being satisfied or highly satisfied with their ICS. Similarly, only $38 \%$ of faculty reported being motivated or highly motivated by their ICS. There was a weak, but statistically significant, association between the faculty's reported understanding of the measurement and rewards aspects of the ICS and the degree to which they reported being motivated to perform specific activities $\left(r^{2}=.08, P<.001\right)$.

\section{Design of Incentive Compensation Systems}

We examined the relationships between percentage of income total that can be incentivized and the outcomes of interest and found positive relationships with satisfaction, motivation, and retention ( $r$ 's $=.20, .19$, $.25 . P<.01$, respectively, see Table 3 ). However, total income available as incentive explained less than $10 \%$ of the variance in faculty satisfaction, motivation, and retention. We then conducted a MANOVA examining the effect of the three income percent levels on these same variables. There was a statistically significant difference on satisfaction, motivation, and retention based on level of total income incentivized, $F=3.42(6,508)$, $P<.01$; Wilks lambda=.92. The means indicating the between-groups effects are reported in Table 4. There were significant differences between all three groups on retention, and there was a significant difference between the first and second groups on satisfaction and motivation. It appears that when the incentive was relatively small in comparison to one's total income, the effect on motivation, satisfaction, and retention was small.

We asked survey respondents whether or not their ICS included incentive opportunities in each of the following categories: clinical productivity, clinical quality, teaching productivity, teaching quality, and research productivity. There were no significant relationships between the reported outcomes and whether or not the clinician was eligible for a clinical productivity incentive. We performed a regression analysis to look at whether or not faculty half days of clinical time was a predictor of clinical motivation, and the model was nonsignificant. As reported in Table 3, incentives in the other four categories were significantly related to satisfaction, retention, and motivation. In addition, there were positive relationships between the number of categories available to faculty and the outcomes, such that faculty that had a greater number of incentive categories available also reported greater satisfaction $(r=.19, P$ $<.01)$, motivation $(r=.27, P<.01)$, and retention $(r=.20, P<.01)$.

Table 5 demonstrates that onefourth $(25.0 \%, 90 / 360)$ of faculty reported that plans had features that could result in lower compensation ("downside potential"), and around one-third of faculty reported that their ICS plans had at least one criteria which could disqualify the faculty from earning incentive ("disqualification criteria," $30.0 \%$ ), team-based incentives (36.7\%), and citizenship/qualitative incentives (27.8\%). Sixty-seven percent of plans offered automated tracking of ICS 
Table 3: Means, Standard Deviation, and Correlation Table for Survey Question Item Constructs

\begin{tabular}{|c|c|c|c|c|c|c|c|c|c|c|c|c|c|c|}
\hline & 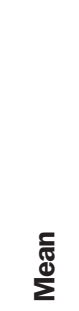 & ஜิ & 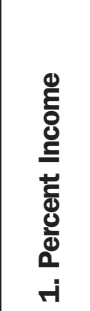 & 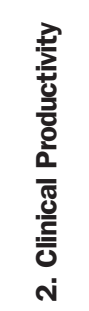 & 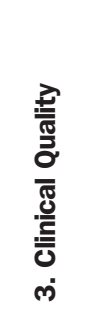 & 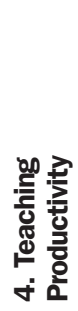 & 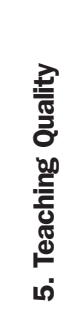 & 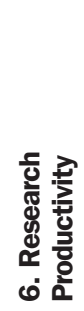 & 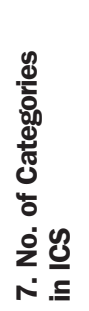 & 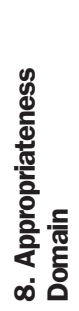 & 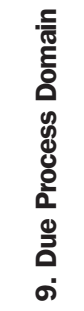 & 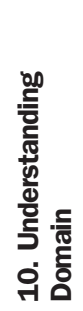 & 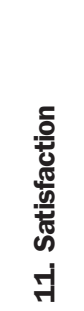 & 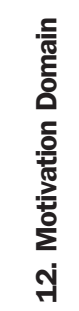 \\
\hline 1. Percent Income & --- & & & & & & & & & & & & & \\
\hline $\begin{array}{l}\text { 2. Clinical } \\
\text { Productivity }\end{array}$ & --- & & $.13^{*}$ & & & & & & & & & & & \\
\hline 3. Clinical Quality & --- & & 0.06 & 0.07 & & & & & & & & & & \\
\hline $\begin{array}{l}\text { 4. Teaching } \\
\text { Productivity }\end{array}$ & --- & & $.17^{*}$ & $.12 *$ & 0.012 & & & & & & & & & \\
\hline $\begin{array}{l}\text { 5. Teaching } \\
\text { Quality }\end{array}$ & -- & & $.13^{*}$ & $-.14 *$ & $.21^{* *}$ & $.26^{* *}$ & & & & & & & & \\
\hline $\begin{array}{l}\text { 6. Research } \\
\text { Productivity }\end{array}$ & --- & & $.27 * *$ & 0.11 & $.13^{*}$ & $.42 * *$ & $.35^{* *}$ & & & & & & & \\
\hline $\begin{array}{l}\text { 7. No. of } \\
\text { Categories in ICS }\end{array}$ & 2.65 & 1.45 & $.29 * *$ & $.27 * *$ & $.51^{* *}$ & $.65^{* *}$ & $.60 * *$ & $.72 * *$ & & & & & & \\
\hline $\begin{array}{l}\text { 8. Appropriateness } \\
\text { Domain }\end{array}$ & 2.82 & 1.12 & $.16^{*}$ & -0.09 & $.15^{*}$ & $.36^{* *}$ & $.34^{* *}$ & $.38 * *$ & $.45^{* *}$ & 0.95 & & & & \\
\hline $\begin{array}{l}\text { 9. Due Process } \\
\text { Domain }\end{array}$ & 3.13 & 0.8 & $.19^{* *}$ & 0.02 & $.27 * *$ & $.19 *$ & $.16^{* *}$ & $.24^{* *}$ & $.33^{*}$ & $.60 * *$ & 0.85 & & & \\
\hline $\begin{array}{l}\text { 10. Understanding } \\
\text { Domain }\end{array}$ & 3.72 & 0.9 & $.17^{* *}$ & 0.09 & $.24 * *$ & 0.09 & 0.1 & $.20 * *$ & $.25^{* *}$ & $.33^{*}$ & $.62^{* *}$ & 0.95 & & \\
\hline 11. Satisfaction & 3.09 & 1.08 & $.20 * *$ & 0.02 & $.12^{*}$ & $.20 * *$ & 0.12 & $.18^{* *}$ & $.25^{* *}$ & $.51^{* *}$ & $.61^{* *}$ & $.39 * *$ & -- & \\
\hline $\begin{array}{l}\text { 12. Motivation } \\
\text { Domain }\end{array}$ & 2.61 & 0.86 & $.19^{* *}$ & 0.02 & $.23^{* *}$ & $.33 * *$ & $.32 * *$ & $.37 * *$ & $.46^{* *}$ & $.57 * *$ & $.58 * *$ & $.30 * *$ & $.44 * *$ & 0.90 \\
\hline 13. Retention & 2.67 & 1.01 & $.25 * *$ & 0.06 & $.22^{* *}$ & $.19 * *$ & $.24^{* *}$ & $.22 * *$ & $.32 * *$ & $.47^{* *}$ & $.58 * *$ & $.34 * *$ & $.59 * *$ & $.61^{* *}$ \\
\hline
\end{tabular}

Notes: $* P<.05,{ }^{* *} P<.01$. When appropriate, Cronbach's coefficient alpha is in bold on the diagonal.

Table 4: Between-Groups Effects From MANOVA of Percent Income Incentivized on Satisfaction, Motivation, and Retention

\begin{tabular}{|l|c|c|c|}
\hline \multicolumn{1}{|c|}{ Amount of Total Income Incentivized } & Mean Satisfaction ${ }^{1}$ & Mean Motivation $^{\mathbf{2}}$ & Mean Retention $^{\mathbf{2}}$ \\
\hline $1-10 \%$ of income incentivized $(\mathrm{N}=222)$ & $\mathbf{2 . 9 5}^{*}$ & $\mathbf{2 . 4 8}^{*}$ & $\mathbf{2 . 5 0}^{*}$ \\
\hline $11-25 \%$ of income incentivized $(\mathrm{N}=88)$ & $\mathbf{3 . 3 4}^{*}$ & $\mathbf{2 . 8 5}^{*}$ & $\mathbf{2 . 9 4}^{*}$ \\
\hline More than $26 \%$ of income incentivized $(\mathrm{N}=8)$ & 3.09 & 2.90 & $\mathbf{3 . 3 8}^{*}$ \\
\hline
\end{tabular}

* Means in bold (for each factor) are significantly different from one another within each outcome.

${ }^{1}$ Based on 5-point Likert-type scale with 1 being "strongly dissatisfied" and 5 being "strongly satisfied".

${ }^{2}$ Based on 5-point Likert-type scale with 1 being "strongly disagree" and 5 being "strongly agree". 
Table 5: Characteristics of Incentive Compensation System for Respondents With More Than $\mathbf{0 \%}$ of Total Income Available Through Incentive Compensation Plan

\begin{tabular}{|l|c|c|}
\hline \multicolumn{1}{|c|}{ Item } & $\begin{array}{c}\text { \% Yes (Number of } \\
\text { Respondents) }\end{array}$ & $\begin{array}{c}\text { \% No (Number of } \\
\text { Respondents) }\end{array}$ \\
\hline ICS has downside potential & $25.0 \%(90)$ & $75.0 \%(270)$ \\
\hline ICS has automated tracking & $67.2 \%(236)$ & $32.8 \%(115)$ \\
\hline ICS has manual tracking & $19.7 \%(71)$ & $80.3 \%(289)$ \\
\hline ICS has team-based performance incentive & $36.7 \%(133)$ & $63.3 \%(229)$ \\
\hline ICS has potential disqualification criteria & $30.0 \%(109)$ & $70.0 \%(253)$ \\
\hline ICS has citizenship incentive & $27.8 \%(100)$ & $72.2 \%(260)$ \\
\hline
\end{tabular}

data. When we examined the relationships between these features and the outcomes, manual tracking (defined as having to keep track of information that was not automatically captured as part of normal workflows), team-based criteria, disqualification criteria, and citizenship were significantly related to reported increased motivation $(r ' s=.17, .15$, $.12, .15, P<.05$, respectively). Manual tracking, team-based criteria and citizenship were significantly related to increased satisfaction ( $r$ 's $=.12, .12$, $.18, P<.05$, respectively), and manual tracking was related to increased retention $(r=.14, P<.05)$.

\section{Faculty Perceptions of Incentive Compensation Systems}

Faculty perceptions of appropriateness, understanding of their ICS, and due process were all significantly related to the outcomes of interest (see Table 3). We conducted a series of regression analyses looking at the relative weight of each of these predictors on the outcomes. Given that the percentage of total income significantly predicted each of the outcomes, this was included in the first step of the regression. As reported in Table 6, in each case, perceptions of appropriateness and due process were significant predictors of satisfaction, motivation, and retention, above and beyond the differences accounted for by percent of incentive. Understanding of the system was not a significant predictor when entered with the first two predictors. In each analysis, appropriateness and due process accounted for significant amounts of variance in satisfaction $\left(R^{2} \Delta=.38, P<.001\right)$, motivation $\left(R^{2} \Delta=.39, P<.001\right)$, and retention $\left(R^{2} \Delta=.31, P<.001\right)$, once we accounted for the variance explained by percent of incentive. This suggests that no matter how much of one's total income the incentive system may include, employees who perceive that the behaviors measured are valid and believe that the system was instituted with due process report greater satisfaction, motivation, and retention.

\section{Discussion}

ICSs are common in academic family medicine, yet the majority of faculty is neither satisfied with nor motivated by their ICS. While the prevalence of incentive-based compensation in this survey is similar to other reports, ${ }^{34}$ this is the first study to examine the effect of ICSs on faculty satisfaction, motivation, and retention across academic family medicine compensation systems.

In times of scarce resources, leaders in academic family medicine must wrestle with the decision of how much incentive they should offer to faculty. Higher levels of incentives can increase short term or overall costs to the institutions, but lack of clarity exists around whether or not incremental increases in incentive dollars lead to increases in behavior change. We demonstrated that, as the percent of income available as an incentive increases, so does motivation and retention. Satisfaction with ICSs may plateau when incentives account for more than $25 \%$ of a faculty member's income, but this should be interpreted with caution due to small numbers of respondents in the group of faculty reporting more than $25 \%$ of their income available as incentives in this study. Future monitoring of trends in this group will be essential as larger incentive programs are developed.

As academic faculty members balance their clinical, teaching, and research roles simultaneously, ICS design has the potential to become very complex as systems try to capture the multiple aspects of a faculty member's effort and productivity. Faculty physicians can be confused by the complexity of the formulas, which are sometimes handed down from the larger organization with few allowances or adaptation by the department. Both of these factors have been shown to impact the incentive programs. ${ }^{18}$ Further research into the extent and impact of these factors on the motivation of academic family physicians is warranted. Administrative leaders are left wondering which aspects are important to incentivize, and how each of those aspects impact faculty satisfaction, motivation, and retention. We demonstrated that with the exception of clinical productivity, faculty satisfaction, motivation, and retention will be higher the more aspects an ICS captures. This relationship implies that recognizing and rewarding the key types of faculty activity is beneficial. In our study, clinical productivity was not related to satisfaction, motivation, or retention. While it is possible that academic faculty 
Table 6: Two-Step Regression of Satisfaction, Motivation, and Retention on Faculty Perceptions

\begin{tabular}{|c|c|c|c|c|c|}
\hline Outcome & Step* & $R$-Square & $\begin{array}{c}\text { R-Square } \\
\text { Change }\end{array}$ & F-Change & Beta \\
\hline \multirow[b]{2}{*}{ Satisfaction } & 1. Percent income & .03 & .03 & 9.33 & $.19^{* * *}$ \\
\hline & $\begin{array}{l}\text { 2. Percent income } \\
\text { Appropriateness } \\
\text { Due process } \\
\text { Understanding }\end{array}$ & .41 & .38 & 56.02 & $\begin{array}{c}.06 \\
.22^{* * *} \\
.46^{* *} \\
.01\end{array}$ \\
\hline \multirow[b]{2}{*}{ Motivation } & 1. Percent income & .04 & .04 & 10.09 & $.19^{* *}$ \\
\hline & $\begin{array}{l}\text { 2. Percent income } \\
\text { Appropriateness } \\
\text { Due process } \\
\text { Understanding }\end{array}$ & .42 & .39 & 57.35 & $\begin{array}{l}.08 \\
.34^{* * *} \\
.41^{* *} \\
-.08 \\
\end{array}$ \\
\hline \multirow[b]{2}{*}{ Retention } & 1. Percent income & .06 & .06 & 17.06 & $.25^{* *}$ \\
\hline & $\begin{array}{l}\text { 2. Percent income } \\
\text { Appropriateness } \\
\text { Due process } \\
\text { Understanding }\end{array}$ & .38 & .31 & 42.75 & $\begin{array}{l}.14 \\
.18^{* *} \\
.46^{* *} \\
-.03\end{array}$ \\
\hline
\end{tabular}

* Step 1: Testing percent income alone. Step 2: Testing percent income and faculty perception of appropriateness, due process, and understanding.

$* *=P<.001$.

physicians may have chosen academics because they have less focus on clinical productivity, further research is needed to evaluate academic faculty satisfaction, motivation, and retention related to clinical activities.

Team-based incentives, citizenship (qualitative measures), and manual tracking are all positively related to faculty satisfaction and motivation in our study. Through their less-constrictive measurement methods, each of these aspects has the potential to capture artifacts of autonomous motivation. This provides support for the hypothesis of other authors that ICSs can negatively impact autonomous motivation. ${ }^{8}$ However, we also believe that the knowledge that these aspects positively impact faculty satisfaction and motivation, will allow administrative leaders to mitigate that negative impact by including these aspects in their ICS designs. While this study did not explore specific examples of how these qualitative incentives were woven into ICSs, we have seen ICS designs that included collective goals that were achieved only when physicians worked together be successful as team-based incentives. We have also observed that allowing faculty to submit lists and/or documentation of activities which they think deserve recognition can be a simple, yet successful, model of a qualitative or citizenship measure.

Some ICSs have disqualification criteria which can serve as a "circuit breaker" for ICS eligibility. These criteria are designed such that a faculty member must meet the criteria or forfeit his or her ability to earn incentive dollars. Based on self-determination theory, such criteria do not reinforce autonomous motivation, but if the faculty view them as achievable, they could be highly motivating. ${ }^{25}$ As expected, we found that the presence of these criteria was positively related to faculty-reported motivation, but not satisfaction or retention.

While we have shown that design of ICSs can impact reported satisfaction, motivation, and retention, we also demonstrated that the manner of ICS implementation has an effect. Faculty perceptions of appropriateness of the measures, understanding of the measurement and reward systems, and perception of due process are all related to satisfaction, motivation, and retention. While understanding is no longer significant when controlled for the percent of income available as incentive, appropriateness and due process are highly correlated $(r=0.62)$ in our study. From our experience, comprehensive ICSs require substantial resources to develop and model, and it becomes tempting to organizations to implement hastily once the design and modeling is complete. Due process requires careful and systematic implementation and communication about the ICS to those who are impacted by it. When this is done well, faculty are more motivated by the ICS. This study is consistent with the American Association of Medical Colleges Faculty Forward reports showing higher engagement related to transparency and receptive communication by administrators. ${ }^{35}$ Without these important aspects, ICSs can be a source of faculty dissatisfaction.

While surveying academic faculty about productivity and job satisfaction has been established as a research methodology, ${ }^{35-37}$ surveying faculty about the impact of ICS programs on satisfaction, motivation, and retention offers new insight into strategies for ICS design and implementation. However, caution must be 
used when interpreting these findings since reported motivation may vary from actual performance and effort allocation. Faculty may perceive their ICS to be more or less financially impacted by activities than what the ICS is actually responsible for, particularly when those same faculty members report they have less than full understanding of their ICS. Thus, the findings do not reflect actual performance outcomes requiring a longitudinal study design of actual observation. In addition, faculty perceptions and satisfaction are closely tied to engagement, and this study does not capture all of the variables that impact faculty engagement.

This study is further limited by having a high percentage of faculty respondents in academic leadership roles due to the constituency of CAFM. However, oversampling of academic leaders can provide a greater degree of insight into how those leaders view the impact of their ICS. With a response rate of $46.5 \%$ on the ICS question subset of this CERA survey, and only $70 \%$ of respondents reporting having an ICS, this is a very limited sample of family medicine faculty members and may not necessarily represent the larger group of academic family physicians and educators across the United States.

When a faculty member believes that an ICS is measuring and rewarding appropriate and important things, and believes that it is doing so in an appropriate and fair way, he or she is more likely to be satisfied with the ICS. The value created by faculty satisfaction not only saves money by reducing faculty turnover ${ }^{38-40}$ but also increases faculty motivation. Compensation is an important factor in faculty satisfaction, ${ }^{41}$ yet the structure, design, and implementation of the ICS plays an important role in faculty perceptions of their compensation system.

\section{References}

1. Ceriani PJ. Compensating and providing incentives for academic physicians: balancing earning, clinical, research, teaching, and administrative responsibilities. J Ambul Care Manage. 1992;15(2):69-78.

2. Shea S, Nickerson KG, Tenenbaum J, et al. Compensation to a department of medicine and its faculty members for the teaching of medical students and house staff. N Engl J Med. 1996;334(3):162-167.

3. Zun LS, Moss D. Bonus/incentive programs to increase physician productivity in academic emergency medicine. Am J Emerg Med. 1996;14(3):334-336.

4. Glass KP, Pieper LE, Berlin MF. Incentivebased physician compensation models. J Ambul Care Manage. 1999;22(3):36-46.

5. Kristal SL, Randall-Kristal KA, Thompson BM, Marx JA. 1998-1999 SAEM emergency medicine faculty salary and benefits survey. Acad Emerg Med. 1999;6(12):1261-1271.

6. Rouan GW, Wones RG, Tsevat J, Galla JH, Dorfmeister JW, Luke RG. Rewarding teaching faculty with a reimbursement plan. J Gen Intern Med. 1999;14(6):327-332.

7. Willis DR, Kelton GM, Saywell RM Jr, Kiovsky $\mathrm{RD}$. An incentive compensation system that rewards individual and corporate productivity. Fam Med. 2004;36(4):270-278.

8. Gagne M, Forest J. The Study of Compensation Systems Through the Lens of Self-determination Theory: Reconciling 35 Years of Debate. Montreal, Canada: Cirano; 2011.

9. Andreae MC, Blad K, Cabana MD. Physician compensation programs in academic medical centers. Health Care Manage Rev. 2006;31(3):251-258.

10. Cassel CK, Jain SH. Assessing individual physician performance: does measurement suppress motivation? JAMA. 2012;307(24):25952596.

11. Chung KC, Song JW, Kim HM, et al. Predictors of job satisfaction among academic faculty members: do instructional and clinical staff differ? Med Educ. 2010;44(10):985-995.

12. Dolan RW, Nesto R, Ellender S, Luccessi C. Results, Knowledge, and Attitudes Regarding an Incentive Compensation Plan in a Hospital-Based, Academic, Employed Physician Multispecialty Group. J Healthc Manag. 2017;62(2):120-133.

13. Pontes MC. Agency theory: a framework for analyzing physician services. Health Care Manage Rev. 1995;20(4):57-67.

14. Campbell SM, Reeves D, Kontopantelis E, Sibbald B, Roland M. Effects of pay for performance on the quality of primary care in England. N Engl J Med. 2009;361(4):368-378.

15. Chien AT, Rosenthal MB. Medicare's physician value-based payment modifier--will the tectonic shift create waves? N Engl J Med. 2013;369(22):2076-2078.

16. McDonald R, Roland M. Pay for performance in primary care in England and California: comparison of unintended consequences. Ann Fam Med. 2009;7(2):121-127.
17. Petersen LA, Woodard LD, Urech T, Daw C, Sookanan S. Does pay-for-performance improve the quality of health care? Ann Intern Med. 2006;145(4):265-272.

18. Eccles RG. The performance measurement manifesto. Harv Bus Rev. 1991;69(1):131-137.

19. Avery DR, Quinones MA. Individual Differences and the Voice Effect: The Moderating Role fo Value of Voice. Group Organ Manage. 2004;29(1):106-124.

20. Mannion R, Davies H. Payment for performance in health care. BMJ. 2008;336(February 9):306-8.

21. Folger R, Konovsky MA, Cropanzano R. A DueProcess Metaphor for Performance-Appraisal. Res Organ Behav. 1992;14:129-177.

22. Abowd JM. Does Performance-Based Managerial Compensation Affect Corporate Performance? Industrial and Labor Relations View. 1990;43(Special Issue):52S-73S.

23. Konovsky MA. Understanding Procedural Justice and Its Impact on Business Organizations. J Manage. 2000;26(3):489-511.

24. Custers T, Hurley J, Klazinga NS, Brown AD Selecting effective incentive structures in health care: A decision framework to support health care purchasers in finding the right incentives to drive performance. BMC Health Serv Res. 2008;8(66):66.

25. Baker GP, Jensen MC, Murphy KJ. Compensation and Incentives: practice vs Theory. $J$ Finance. 1988;XLIII(3):593-616.

26. Stites S, Vansaghi L, Pingleton S, Cox G, Paolo A. Aligning compensation with education: design and implementation of the Educational Value Unit (EVU) system in an academic internal medicine department. Acad Med. 2005;80(12):1100-1106.

27. Reece EA, Nugent O, Wheeler RP, Smith CW, Hough AJ, Winter C. Adapting industry-style business model to academia in a system of Performance-based Incentive Compensation. Acad Med. 2008;83(1):76-84.

28. Stites S, Steffen P, Turner S, Pingleton S. Aligning clinical compensation with clinical productivity: design and implementation of the financial value unit (FVU) system in an academic department of internal medicine. Acad Med. 2013;88(7):946-951.

29. Glasziou PP, Buchan H, Del Mar C, et al. When financial incentives do more good than harm: a checklist. BMJ. 2012;345(August 14):e5047.

30. Huselid MA. The Impact of Human Resource Management Practice on Turnover, Productivity, and Corporate Financial Performance. Acad Manage J. 1995;38(3):635-672.

31. Schloss EP, Flanagan DM, Culler CL, Wright $\mathrm{AL}$. Some hidden costs of faculty turnover in clinical departments in one academic medical center. Acad Med. 2009;84(1):32-36.

32. Mainous AG III, Seehusen D, Shokar N. CAFM Educational Research Alliance (CERA) 2011 Residency director survey: background, methods, and respondent characteristics. Fam Med. 2012;44(10):691-693

33. Shokar N, Bergus G, Bazemore A, et al. Calling all scholars to the council of academic family medicine educational research alliance (CERA). Ann Fam Med. 2011;9(4):372-373. 
34. Bowers J. The different ways hospitals pay: Incentive compensation aims to improve quality and productivity. ACP Hospitalist. http://www. acphospitalist.org/archives/2010/10/money.htm. Accessed October, 2017.

35. Bunton SA, Corrice AM, Pollart SM, et al Predictors of workplace satisfaction for U.S. medical school faculty in an era of change and challenge. Acad Med. 2012;87(5):574-581.

36. Carr PL, Ash AS, Friedman RH, et al. Relation of family responsibilities and gender to the productivity and career satisfaction of medical faculty. Ann Intern Med. 1998;129(7):532-538.
37. Palepu A, Carr PL, Friedman RH, Ash AS, Moskowitz MA. Specialty choices, compensation, and career satisfaction of underrepresented minority faculty in academic medicine. Acad Med. 2000;75(2):157-160.

38. Williams ES, Skinner AC. Outcomes of physician job satisfaction: a narrative review, implications, and directions for future research. Health Care Manage Rev. 2003;28(2):119-139.

39. Misra-Hebert AD, Kay R, Stoller JK. A review of physician turnover: rates, causes, and consequences. Am J Qual. 2004; 19(2):56-66.
40. Buchbinder SB, Wilson M, Melick CF, Powe NR. Primary care physician job satisfaction and turnover. Am J Manag Care. 2001;7(7):701713.

41. Coyle YM, Aday LA, Battles JB, Hynan LS. Measuring and predicting academic generalists' work satisfaction: implications for retaining faculty. Acad Med. 1999;74(9):1021-1027. 